\title{
Intra-epithelial mast cells in human airway epithelium: evidence for smoking-induced changes in their frequency
}

\author{
DAVID LAMB, ALAN LUMSDEN
}

From the Department of Pathology, University of Edinburgh, Edinburgh

ABSTRACT A morphological and quantitative study was performed on the respiratory epithelium of human distal airways in 20 lungs removed at operation for the treatment of carcinoma. Using $1 \mu \mathrm{m}$ araldite sections stained with Toluidine Blue for light microscopy, with further electron microscopic study where required, we have described mast cells in the epithelium of bronchioles, terminal bronchioles, and respiratory bronchioles. Examination of these cells at both microscopic levels demonstrates many of the typical features of mast cells-namely, metachromatic granules on staining with toluidine blue at light microscopic level, surface microvillous processes, and numerous dense intracytoplasmic granules with a whorled substructure at electron microscopy. Furthermore, we have identified cells devoid of granular material which may be recognised as mast cells by virtue of their nuclear and cell surface characteristics-the occurrence of a spectrum of change between those cells devoid of granular material and those with full granule content; and a few cells in which we found both typical dense, whorled granules and large lucent vacuoles devoid of such material. Quantitation of all respiratory epithelial cells by light microscopy shows that mast cells comprise $0-2 \%$ of the total population. A higher proportion of mast cells was found in the epithelium of smokers than in non-smokers. Because of the presence of many epithelial mast cells devoid of granule content, we suggest that the use of traditional $4 \mu \mathrm{m}$ paraffin sections stained with thiazine dyes to study mast cells would lead to a marked underestimation of the epithelial population.

Mast cells are based within the connective tissue component of a tissue and the size of a mast cell population in a given organ normally correlates well with its connective tissue content. ${ }^{1}$ In the lungs, mast cells can be demonstrated in the submucosal connective tissue, in glands around block vessels, and in alveolar walls. Basophiloid cells (believed to be mast cells) have also been demonstrated by brush biopsy as occurring within the respiratory mucosa of allergic dogs ${ }^{2}$ and allergic monkeys. ${ }^{3}$ Furthermore, mast cells have been observed within the gastrointestinal epithelium of man. ${ }^{4}$ Brinkman $^{5}$ was the first to provide electron microscopic evidence of mast cells in the epithelium of human proximal airways.

This work was performed as part of a quantitative examination of all respiratory epithelial cell types with particular emphasis on human distal airways.

In previous studies, identification of mast cells had

Address for reprint requests: Dr David Lamb, Department of Pathology, University of Edinburgh, Teviot Place, Edinburgh EH8 9AG. depended on the presence of metachromasia on staining with thiazine dyes. ${ }^{6}$ Consequently, mast cells devoid of granule content prove difficult to detect in standard $4 \mu \mathrm{m}$ paraffin sections. Using 1 $\mu \mathrm{m}$ araldite sections at light microscopic level with the facility of further electron microscopic examination of the same cell, where required, we have been able to note the distinctive features of these cells at both microscopic levels. Thus it is possible to detect those intra-epithelial mast cells which appear to be devoid of granular material and also those showing full granule content and thus metachromasia on staining with $1 \%$ toluidine blue.

Finally, we emphasise the morphological differences between the mast cell and two other cell types with which confusion may arise, the basophil and the intra-epithelial neuroendocrine cell.

\section{Methods}

Material used in this study consisted of human lung tissue removed at operation for carcinoma. Twenty 
cases were examined consisting of 14 pneumonectomy and six lobectomy specimens. The lungs were fixed immediately on removal from the patient by a perfusion fixation procedure using $2 \%$ EM grade glutaraldehyde and left for a further 24 hours before being sliced into $1 \mathrm{~cm}$ sagittal sections for routine pathological examination. Tissue blocks required for study were selected from areas showing: (1) no blockage of associated bronchi by tumour, mucus, or pus; (2) no macroscopic evidence of previous or current infection; (3) no obvious involvement by tumour. In practice, only material from an apparently normal lobe in the case of pneumonectomy specimens and from lobectomy specimens resected for small peripheral lesions was used.

Since the emphasis of this study was on human distal airways, tissue blocks were taken from a site approximately $1-2 \mathrm{~cm}$ from, and parallel with, the pleural surface of the lung, each block being approximately $2.5 \times 1.5 \times 0.5 \mathrm{~cm}$ in size.

The lung tissue was then processed using a modified electron microscopic technique, finally being impregnated and embedded in araldite. Details of this schedule are given in table 1 .

The tissue was initially sectioned on a Reichert Jung Autocut Microtome using a tungsten carbide knife; this method while allowing identification of small distal airways was not satisfactory for direct light microscopic examination of respiratory epithelial cells. Consequently, it proved necessary to trim the desired airways from the large araldite blocks for further sectioning on a Porter Bloom semiautomatic microtome with a $6 \mathrm{~mm}$ glass knife. By

\section{Table 1 Processing schedule}

1 Initial fixation via cannulation of main bronchus with $2 \% \mathrm{EM}$ grade gluteraldehyde in $0.2 \mathrm{M}$ cacodylate buffer, at room temperature for 24 hours.

2 After selection of tissue blocks they were reimmersed in glutaraldehyde for a further 24 hours.

3 After washing in $10 \%$ ethanol osmium tetroxide used as secondary fixation for two to three hours.

4 Dehydration over 22 hours was then performed in graded ethanol solution (10-100\% ethanol).

5 Propylene oxide was used as a link reagent-2 $2 \times 2$ hours.

6 Tissue was immediately transferred from the link reagent to a freshly prepared araldite mixture and impregnation carried out under a vacuum of 28 inches of mercury.

7 After removal of air from the tissue, the above process was repeated before the tissue was embedded in a fresh araldite mixture and hardened at $60^{\circ} \mathrm{C}$ for $10-14$ days.

The araldite mixture

$$
\begin{gathered}
\text { Preparation-Solution } A\left\{\begin{array}{r}
200 \mathrm{ml} \text { araldite } \\
200 \mathrm{ml} \text { duodecenyl succinic } \\
\text { anhydride }
\end{array}\right. \\
\text { Solution } B\left\{\begin{array}{c}
1 \mathrm{ml} \mathrm{HY} 960 \text { accelerator } \\
20 \mathrm{ml} \text { dibutylphthalate }
\end{array}\right.
\end{gathered}
$$

The working solution is prepared by mixing $200 \mathrm{ml}$ solution $\mathrm{A}$ and $10 \mathrm{ml}$ solution $B$. this method it was possible to make use of araldite blocks of a size $6 \mathrm{~mm} \times 4 \mathrm{~mm}$. Sections were then cut at a thickness of $1 \mu \mathrm{m}$. At least three sections were obtained per airway at intervals of at least $10 \mu \mathrm{m}$. Staining was achieved using $1 \%$ toluidine blue in $1 \%$ sodium tetraborate.

The area required for electron microscopic examination was selected from the tissue blocks as prepared above. Ultra-thin sections were then prepared and stained with uranyl nitrate/lead citrate.

The airway under examination was firstly classified according to level. A bronchiole was considered to be an airway less than $3 \mathrm{~mm}$ in size with no cartilage or glands in its wall. Respiratory bronchioles were readily identified by virtue of alveoli arising directly from their walls. Terminal bronchioles could only be reliably identified when a longitudinal section showed continuity with respiratory bronchioles. Hence terminal bronchioles seen in transverse section would be classified as bronchioles. Furthermore small bronchi not showing cartilage or glands in the plane of section would be classified as bronchioles. These discrepancies in classification would be unlikely to affect the results greatly.

The area of epithelium to be studied was largely selected at random-although in some cases it was necessary to avoid areas of tangential cutting. Cells were counted on each of 10 consecutive high power fields per section (approximately 300 cells) with one count on each of the three sections per airway. A total of 120 airways was examined (five per each smoking patient, 10 per nonsmoking patient) ing approximately 90000 cells. Results were expressed as a percentage of total epithelial cells. In three cases it was not possible to identify terminal/ respiratory bronchioles.

A number of different epithelial cells may be identified at light microscopic level using toluidine blue stained $1 \mathrm{~mm}$ araldite sections. For quantitative purposes a mast cell was considered to be a basally situated cell with metachromatic granules or large lucent vacuoles or both; ciliated cells were identified by their apical cells; goblet cells by their large granules which filled the cytoplasm; Clara cells by their apical luminal bulge, which contained small dense granules; and basal cells by their position and absence of other features. Identification of other cell types and variants of the typical higher microscopic appearances of the cells described above required further examination by electron microscopy.

Mast cells measure approximately 10-15 $\times 5 \mu \mathrm{m}$. Variations in cell size may affect the results of a quantitative study such as this. However, although this is noted, no correction factors have been applied.

Electron microscopy was used to examine regions 
of epithelium previously quantified at light microscopic level. In many cases it proved possible to examine the same cell by both methods. Thus we were able to confirm that those basally situated cells devoid of granules and seen by light microscopy were indeed mast cells-on the basis of cell surface and nuclear characteristics together with position in the epithelium and sparse residual granular content visible on electron microscopy.

It was decided that the most reliable method available to use for obtaining a detailed smoking history was by distributing questionnaires directly to the patient after operation. In three patients, however, this could not be used because of death during operation (one case) and refusal of permission by the general practitioner to approach his patient (two cases). Under these circumstances, information was obtained from clinical notes and general practitioners. It was thus possible to produce three subdivisions as follows.

1 Smokers who smoked up to the time of their operation (including those who reduced their consumption)-nine patients.

2 Those who stopped for a variable period (three weeks-three months) before operation-six patients.

3 Nonsmokers (this includes one patient who stopped 17 years previously)-four patients.

In the case of one smoker no immediate preoperative data were available. He has thus been classified as smoking up to the time of operation.

\section{Results}

\section{LIGHT AND ELECTRON MICROSCOPIC}

\section{APPEARANCE OF EPITHELIAL MAST CELLS}

By light microscopy using $1 \mu \mathrm{m}$ araldite sections mast cells were consistently basally situated within the epithelium (fig 1). Mast cells were characterised by a large oval central nucleus, the cytoplasm being occupied by either pink/red metachromatic granules or large vacuoles apparently devoid of granular content, with all degrees of gradation between the two (fig 1). Whereas those with metachromatic granules are readily recognisable as mast cells, this was not the case with those devoid of granules. Thus it was necessary to confirm the identity of these cells by examination at a higher ultrastructural level.

Electron microscopy confirmed the basal situation of mast cells (fig 2) and that the striking difference in appearance between the cells with light microscopy was caused by a marked variation in granule content. Many cells contained a cytoplasm filled with large electron dense granules $(0.4-0.8 \mu \mathrm{m}$ diameter). These granules contained one or two notable features. One of these was a thumb-print pattern (fig 3), a continuous whorling or scroll-type substructure within the granule. Periodicity of the scroll was approximately $0.02-0.05 \mu \mathrm{m}$. Clarity of the scroll was found to be very variable depending upon the density of the granule. A number of small tubular structures $0.01-0.03 \mu \mathrm{m}$ in diameter could also be demonstrated. Frequently these were found clustered together within the scroll-like granules. Such a granular substructure is a recognised specific feature of the mast cell granule. ${ }^{1}$

All granules appeared to be membrane-bound. It is notable that at no time did the granule of the epithelial mast cell appear as dense as those of the mast cells in its submucosa in the same sections.

A number of cells were found which contained large numbers of circular electron lucent vacuoles which almost totally replaced the cytoplasm. The vacuoles measured $0.5-1.3 \mu \mathrm{m}$ diameter and also

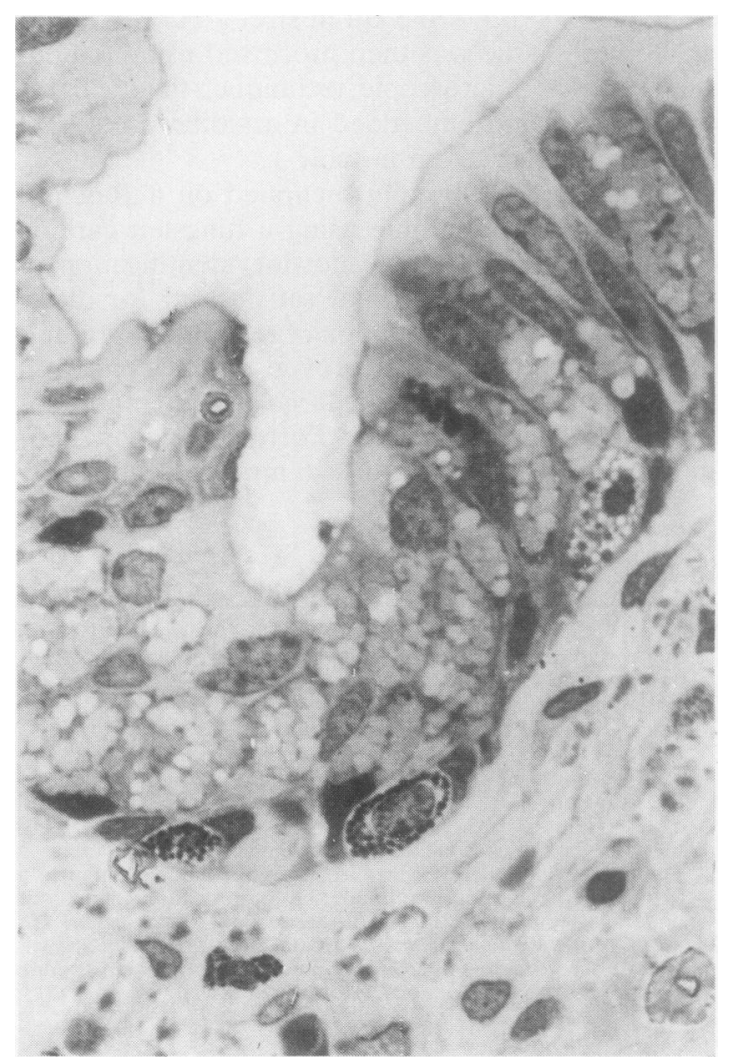

Fig 1 Human bronchiolar epithelium showing the presence of basally situated mast cells. Three mast cells are present, the two to the left showing granulated cytoplasm, the one to the right showing largely vacuolated cytoplasm with only occasional granules. Araldite embedded tissue cut at $1 \mathrm{um}$ was stained with toluidine blue.

Magnification $\times 1000$. 


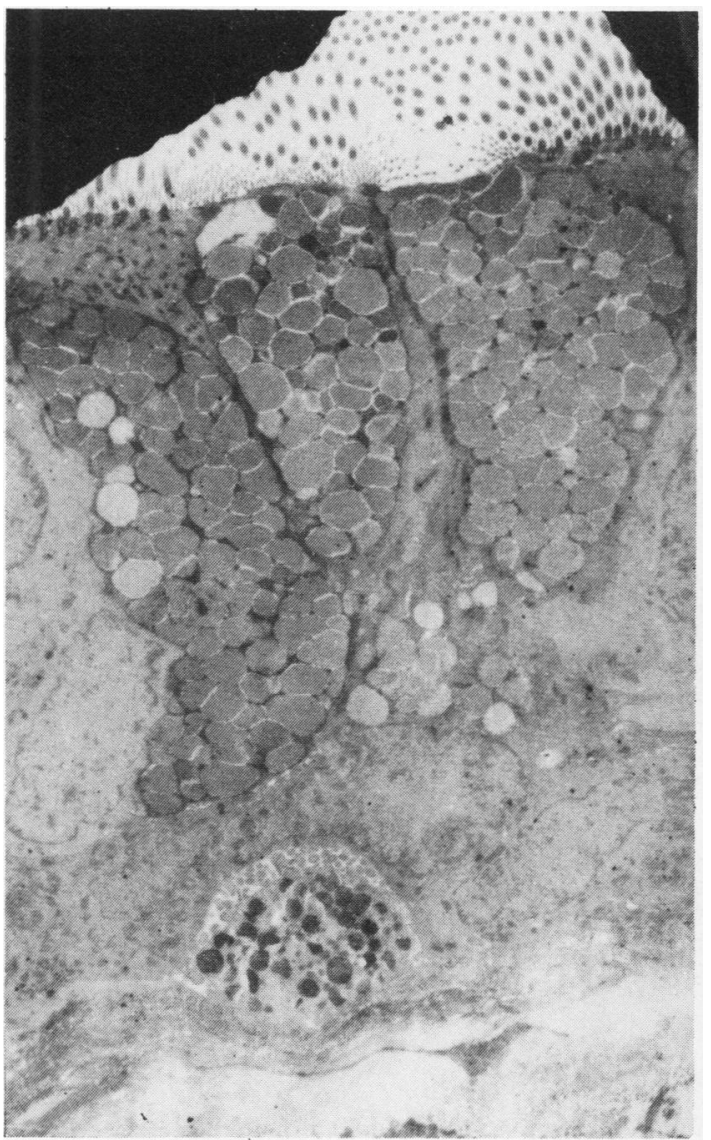

Fig 2 Electron micrograph of bronchiolar epithelium. A mast cell is visible, basally situated within the epithelium. The characteristic cell surface processes and numerous dense intracytoplasmic granules are well demonstrated. Above the mast cell are three goblet cells.

Magnification $\times 3750$.

appeared to be bound by a single membrane. The vacuoles contained only a little sparse granular material (fig 4).

Cells were also observed in which both types of granule, with and without electron-dense material, were present and all degrees of gradation between the two extremes described above could be observed.

Although the above differences were noted, all the cells shared a number of other morphological features. They were round to oval in shape and measured 10-15 $\times 5 \mu \mathrm{m}$. The cell surface of both showed a very characteristic abundance of elongated processes usually lying parallel with the cell surface, the ends occasionally appearing enlarged and club- like. These processes normally surrounded the entire cell, though frequently were more prominent on the luminal side. They contained an oval nucleus of variable size, $6-8 \times 1-3 \mu \mathrm{m}$. No nucleoli were observed but a characteristic pattern of peripheral chromatin clumping was usual. A few elongated mitochondria plus a little rough endoplasmic reticulum and Golgi apparatus were inconsistently found. These cells were normally basally situated within the epithelium, frequently in contact with the basement membrane. At no time were mast cells observed in contact with the luminal surface of the epithelium or indeed, in transit through the basement membrane.

It was thus concluded that all the variants described above represented epithelial mast cells. Such cells were identified as occurring within the epithelium of bronchioles, terminal bronchioles, respiratory bronchioles, and the few large proximal bronchi examined.

\section{QUANTITATIVE VARIATIONS IN MAST CELL}

DENSITY IN RESPIRATORY EPITHELIUM

Mast cell numbers were quantified as part of a general examination of all respiratory epithelial cells. Results are thus expressed as a percentage of total cell count rather than an absolute number per unit area. Furthermore, we have subdivided (where required) the total mast cell population into two groups-those containing some granular material and those vacuolated cells totally devoid of stained granules as seen by light microscopy. Detailed results are shown in table 2 .

\section{Comparison of smokers versus nonsmokers (see fig 5)}

In the bronchioles of all smokers, mast cells (total count) were found to constitute a sizable proportion of all epithelial cells-range $0.44-2 \cdot 16 \%$ of total with mean $=1 \cdot 27 \%$. Comparing those who stopped smoking before operation (mean $=1.54 \%$ ) with those who continued to smoke (mean $=1 \cdot 11 \%$ ) a difference in mast cell frequency is noted but this is not significant at the $5 \%$ level. In nonsmokers, mast cells comprised $0 \cdot 12-0.42 \%$ of total epithelial cells (mean $=0.26 \%$ ); this reveals a marked difference in the size of the bronchiolar mast cell population between smokers and nonsmokers $(p<0.001)$.

Un examination of terminal/respiratory bronchioles the range of mast cell frequency in smokers was $0-4.15 \%$ with a mean $=0.85 \%$. It should be noted that the upper value of $4.15 \%$ was greatly in excess of the next highest $=1.46 \%$. Great emphasis was placed on selecting material from lung areas not involved in a disease process. However, it remains 


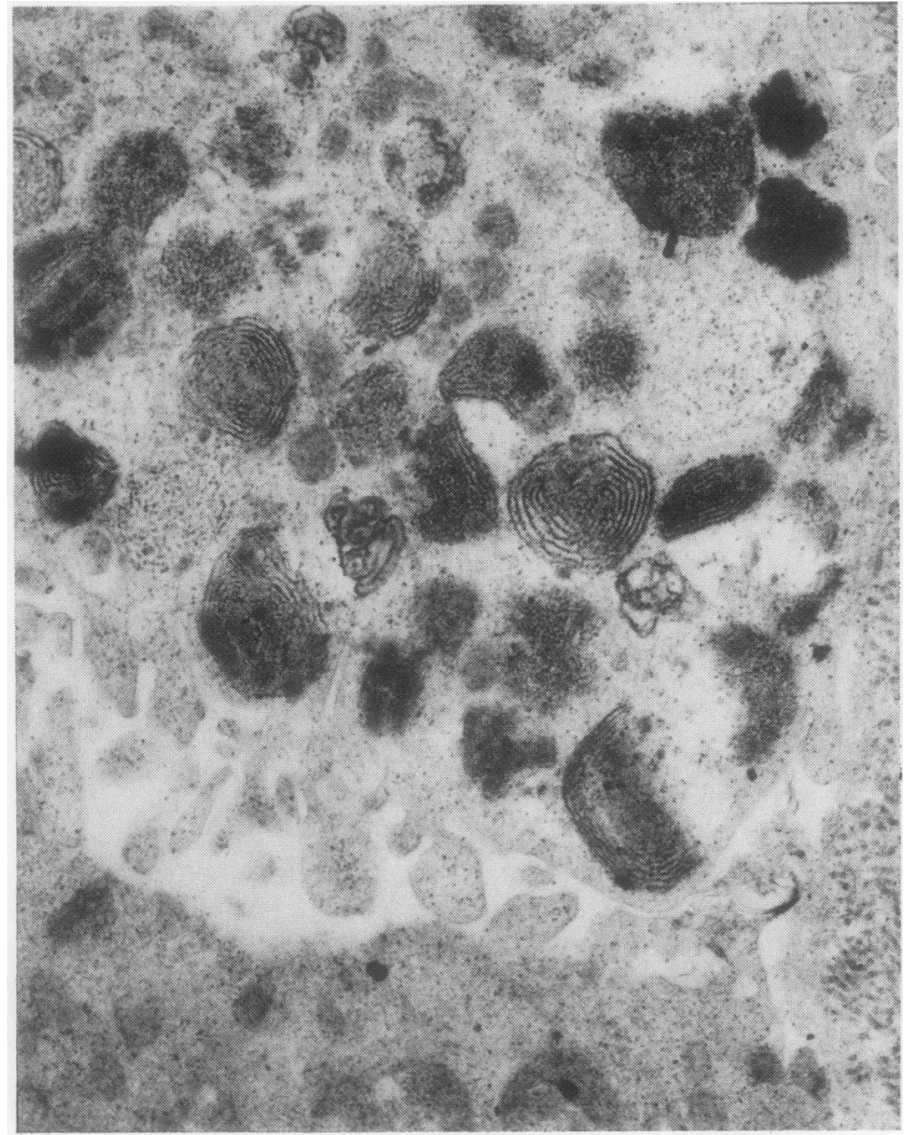

Fig 3 A higher magnification of a basally situated mast cell showing the characteristic intracytoplasmic granules. The whorled substructure of the mast cell granules, thumb-printing, is readily visible. The club-like surface processes are also well seen. Electron micrograph magnification $\times 20000$. possible that this inappropriately high percentage is a reflection of local inflammation. In nonsmokers the range was $0-0.14 \%$, mean $=0.04 \%$. Again this reveals an apparent increase in the number of mast cells in the respiratory epithelium of smokers though no intergroup comparison reached significance at the $5 \%$ level. No consistent relationship could be demonstrated between the total mast cell count and the number showing loss of granule content. In the bronchioles of smokers, the percentage of vacuolated mast cells was variable, $0-36 \%$ of the total mast cell count, while in nonsmokers this figure was 0-93\%.

At terminal/respiratory bronchiole level, mast cells devoid of granular material comprised 0-100\% of total mast cell count in smokers, whereas in nonsmokers no cells with loss of granular content were observed.

\section{Other variables}

In most cases the frequency of mast cells appeared to be greatest in the bronchioles. Furthermore, no consistent relationship was detected between the size of mast cell population observed in the bronchioles and their frequency in the terminal/ respiratory bronchioles of each case.

Though we could demonstrate a difference in mast cell numbers associated with smoking no dose related response was found taking actual numbers of cigarettes smoked into account, or any relationship to the type of smoking material.

\section{Discussion}

In this study we have demonstrated the occurrence of mast cells within the respiratory epithelium of human distal airways. Only those resection specimens containing areas of macroscopically normal tissue were selected in an attempt to minimise any possible effects of the neoplastic disease or its complications on the respiratory epithelium. In addition to recognising the occurrence of mast cells, it has also been possible to identify a spectrum of change of mast cell morphology from those with an appar- 
ently full granular content to those virtually devoid of such material.

Appearances with similar marked vacuolation have been described in human mast cells found in a number of sites-for example, gastric mucosa, small intestine in Crohn's disease, ${ }^{8}$ skin. ${ }^{910}$ These changes may be interpreted as indicating mast cell degranulation. However, it has been debated whether such degranulation is ever a normal physiological response. " Indeed, appearances such as those described have been reported as a consequence of fixation and processing artefacts. ${ }^{12}$ Nevertheless, there remains much evidence that this morphological appearance represents degranulation rather than dissolution by fixative. Firstly, in the course of this study we frequently observed cells devoid of granular material adjacent to those with full granule complement (fig 1). This would not be expected from fixation artefact. Secondly, a study based on the morphological changes of pulmonary (interstitial) mast cells in dogs subject to shock demonstrated vacuolation in the experimental group. No such change was noted in the control group despite both being subject to a perfusion fixation procedure using $3.5 \%$ glutaraldehyde. ${ }^{13}$ Therefore, although some doubt must still remain as to the mechanism of vacuolation, we feel that there is much to indicate that this morphological appearance reflects actual degranulation. The difference between epithelial and subepithelial mast cells in this respect might suggest some anaesthetic effect, but we were unable to find any relationship between degranulation and the type or length of anaesthesia.

We have demonstrated that mast cells are frequently found in the respiratory epithelium and would propose that techniques using $4 \mu \mathrm{m}$ paraffin sections stained with toluidine blue are inappropriate for the study of epithelial mast cell density. Loss of granule substance-whether by artefact or degranulation-undoubtedly affects the ability to detect these cells by techniques dependent on their metachromasia. However, at no time in the study could we detect vacuolation of mast cells in the submucosa and thus toluidine blue stained paraffin

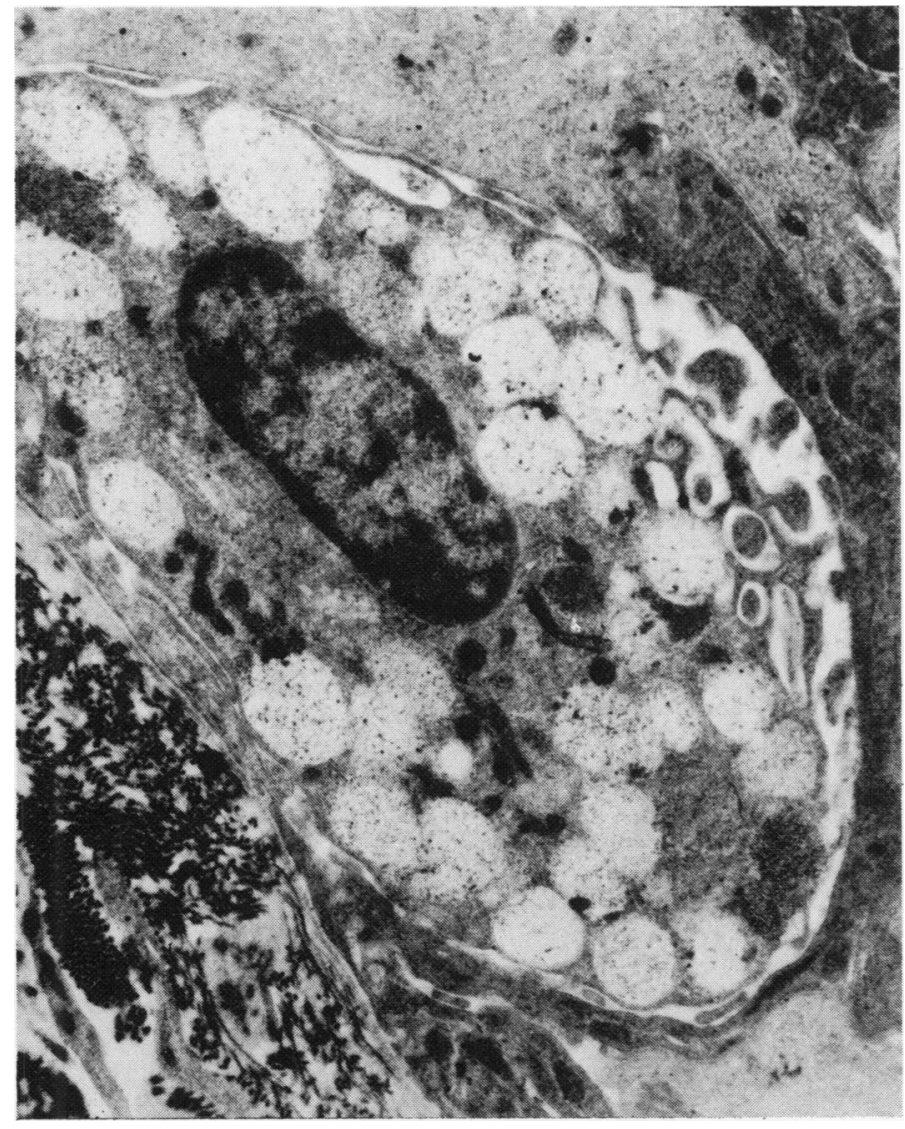

Fig 4 A basally situated mast cell showing almost complete degranulation. A few granules retain a little electron-dense material. The surface microvillous processes are well demonstrated. Electron micrograph magnification $\times 8500$. 
Table 2 Mast cells in individual patients, expressed as percentage of total epithelial cells

\begin{tabular}{|c|c|c|c|c|c|c|}
\hline \multicolumn{4}{|c|}{ Bronchioles } & \multicolumn{3}{|c|}{ Term/resp bronchioles } \\
\hline Patient & $\begin{array}{l}\text { With } \\
\text { granular } \\
\text { material }\end{array}$ & $\begin{array}{l}\text { Without } \\
\text { granular } \\
\text { material }\end{array}$ & Total & $\begin{array}{l}\text { With } \\
\text { granular } \\
\text { material }\end{array}$ & $\begin{array}{l}\text { Without } \\
\text { granular } \\
\text { material }\end{array}$ & Total \\
\hline $\begin{array}{l}\text { A } \\
\text { B } \\
\text { C } \\
\text { D } \\
\text { E } \\
\text { F } \\
\text { G } \\
\text { H } \\
\text { I } \\
\text { J } \\
\text { K } \\
\text { L } \\
\text { M } \\
\text { N } \\
\text { O } \\
\text { P } \\
\text { Q } \\
\text { R } \\
\text { S } \\
\text { T }\end{array}$ & $\begin{array}{l}0.80 \\
1.40 \\
1.44 \\
1.06 \\
0.99 \\
1.36 \\
0.60 \\
0.44 \\
0.63 \\
1.46 \\
0.73 \\
1.74 \\
1.57 \\
0.50 \\
1.93 \\
1.73 \\
0.13 \\
0.03 \\
0.07 \\
0.03\end{array}$ & $\begin{array}{l}0 \cdot 04 \\
0 \\
0 \\
0 \cdot 25 \\
0 \cdot 06 \\
0 \cdot 20 \\
0 \cdot 10 \\
0 \\
0 \cdot 36 \\
0 \\
0 \cdot 27 \\
0 \\
0 \\
0 \cdot 18 \\
0 \cdot 18 \\
0 \cdot 43 \\
0 \\
0 \cdot 09 \\
0 \cdot 30 \\
0.39\end{array}$ & $\begin{array}{l}0.84 \\
1.40 \\
1.44 \\
1.31 \\
1.05 \\
1.56 \\
0.70 \\
0.44 \\
0.99 \\
1.46 \\
1.00 \\
1.74 \\
1.57 \\
0.68 \\
2.11 \\
2.16 \\
0.13 \\
0.12 \\
0.37 \\
0.42\end{array}$ & $\begin{array}{l}0 \\
0 \\
1 \cdot 28 \\
0 \cdot 78 \\
0 \cdot 56 \\
0 \cdot 73 \\
0 \\
0 \\
-1 \cdot 30 \\
\overline{1} \\
0 \cdot 51 \\
0 \cdot 38 \\
0 \\
0 \\
0 \cdot 12 \\
0 \\
0 \cdot 14 \\
0 \\
-\end{array}$ & $\begin{array}{l}0 \cdot 64 \\
0 \cdot 34 \\
2 \cdot 87 \\
0 \\
0 \\
0 \cdot 43 \\
0 \cdot 26 \\
0 \\
\frac{0}{0 \cdot 16} \\
\overline{0} \\
0 \cdot 71 \\
0 \\
0 \cdot 86 \\
0 \\
0 \\
0 \\
0 \\
-\end{array}$ & $\begin{array}{l}0.64 \\
0.34 \\
4 \cdot 15 \\
0.78 \\
0.56 \\
1 \cdot 16 \\
0.26 \\
0 \\
\overline{1.46} \\
\overline{0} \\
0 \cdot 51 \\
1 \cdot 09 \\
0 \\
0 \cdot 86 \\
0 \cdot 12 \\
0 \\
0 \cdot 14 \\
0 \\
-\end{array}$ \\
\hline
\end{tabular}

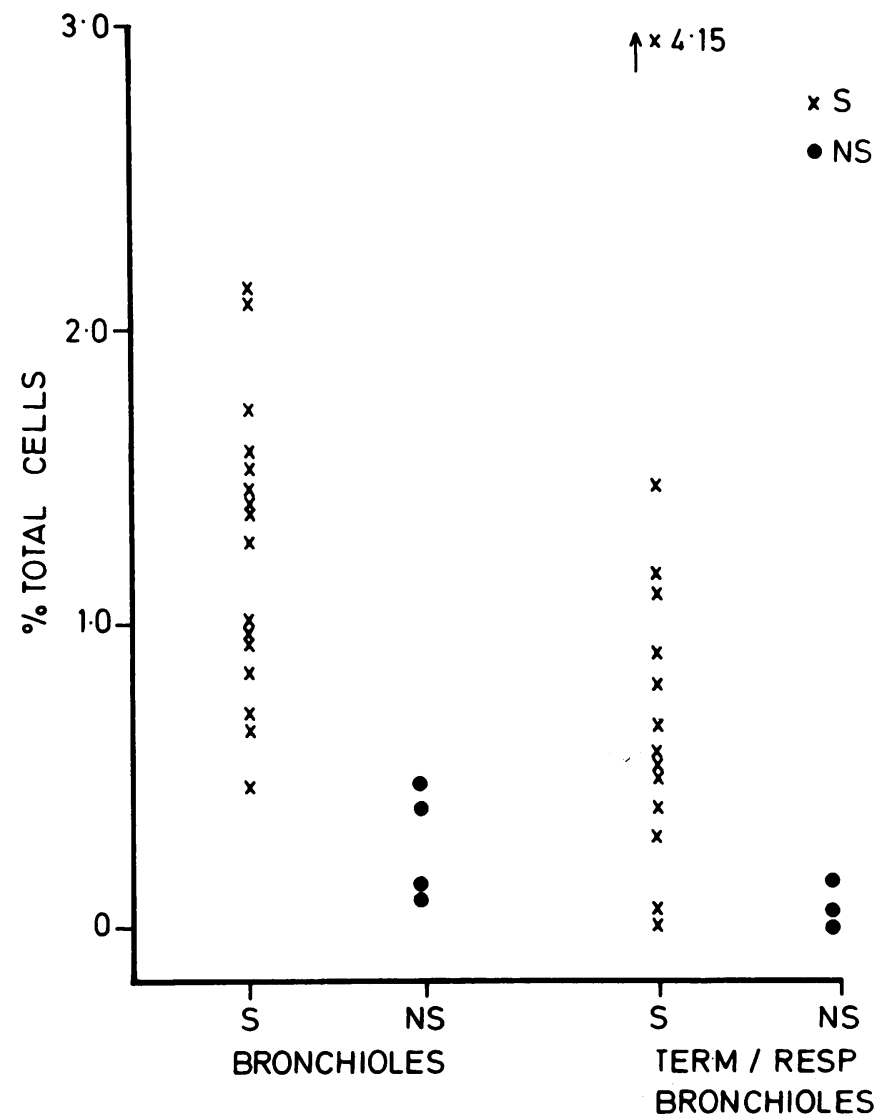

Fig 5 Mast cells as percentage of total cells in smokers (S) and nonsmokers (NS). 
sections may accurately reflect cell numbers in other than epithelial sites. Using such a technique Connell ${ }^{14}$ studied the distribution of mast cells in human proximal airways. They were found to be most frequent at the ends of cartilagenous rings, between cartilage and muscle and external to the basement membrane of the submucosal glands. No mast cells were identified in either the epithelium or lumen. In contrast, Brinkman ${ }^{5}$ produced the only previous electron microscopic description of intra-epithelial mast cells in human airways. He identified these cells in large proximal airways and, although giving no quantitative data, described the cells as rare. A more recent study concerned the number and distribution of mast cells in monkey lungs. ${ }^{15}$ Mast cells were identified as occurring above the basement membrane at all airway levels. They were found to account for up to 1 in 100000 epithelial cells, with an apparent increased density in peripheral airways. In the present study whereas quantitation was not carried out in proximal airways there was a strong impression of a higher number of mast cells in bronchioles than in bronchi.

Our results have revealed a wide variation in mast cell density with apparently more in smokers than nonsmokers. The mechanism by which this occurs and the consequences of these changes are not understood. Having used the technique of perfusion fixation via the bronchial tree, we were not able to comment on mast cells within the airway lumen. However, results of a previous study ${ }^{16}$ demonstrated the presence of histamine-containing cells after bronchial lavage in human subjects. These cells consisted of both mast cells and basophil leucocytes, the latter being frequently confused with mast cells. Whereas both cells have metachromatic granules on staining with toluidine blue ${ }^{17}$ they may be distinguished by virtue of the fact that basophils contain a lobed nucleus and less densely packed granules, lack the surface processes of the mast cell, and do not show the characteristic whorled substructure to their granules. ${ }^{18}$ No intra-epithelial basophils were identified during the course of this study.

A number of previous studies have reported the occurrence of granule-containing endocrine cells in the respiratory epithelium of human bronchi, ${ }^{1920}$ and in submucosal glands. ${ }^{21}$ Such cells have been variously termed Feyrter cells, Kulchitsky cells, clear cells, and neurosecretory cells. ${ }^{223}$ Like the mast cell these endocrine cells are also basally situated within the epithelium although in contrast have occasionally been observed to be in contact with the luminal surface of the epithelium. ${ }^{24}$ They contain numerous spherical intracytoplasmic granules, 1200-2000 $\AA$ diameter, contain an electron-dense core surrounded by an electron-lucent halo, and are bound by a unit membrane. ${ }^{20}$ These cells may be distinguished readily from mast cells on the basis of granule size and substructure.

The role of the mast cell in both the physiological and pathological situation has been the subject of much controversy. We have little evidence for the functional significance of the variations in epithelial mast cell density which we have shown. Retrospective study of the preoperative respiratory function tests reveal a statistically nonsignificant trend whereby those with the larger epithelial mast cell populations have greater degrees of airways obstruction. This may be simply an expression of a common relationship of both variables to the smoking history.

We would like to thank the Scottish Hospital Endowments Research Trust, the Scottish Home and Health Department, and the National Coal Board for financial support.

\section{References}

' Bloom GD. Structural and biochemical characteristics of mast cells. In: Zweifach BW, ed. The inflammatory process. Vol 3. New York: Academic Press, 1974:545-9.

${ }^{2}$ Patterson R, Tomita Y, Oh SH, Suszko IM, Pruzansky JJ. Respiratory mast cells and basophiloid cells. Clin Exp Immunol 1974;16:223-34.

${ }^{3}$ Patterson R, Suszko IM. Primate respiratory mast cells. $J$ Immunol 1971;106:55,1274-83.

4 Dobbins WO, Tomasini JT, Rollins EL. Electron and light microscopic identification of the mast cell of the gastrointestinal tract. Gastroenterology 1969;56:268-79.

${ }^{5}$ Brinkman GL. The mast cell in normal human bronchus and lung. J Ultrastruct Res 1968;23:115-23.

- Enerback L. Mast cells in rat GI mucosa: effects of fixation. Acta Pathol Microbiol Scand 1966;66:289-302.

' Steer HW, Colin-Jones DG, Bulmer D. Human mast cell degranulation and vacuolation. $J$ Anat (Lond) 1974;118:369.

8 Dvorak AM, Monahan RA, Osage JE, Dickerson GR. Mast cell degranulation in Crohn's disease. Lancet 1978;1:498.

${ }^{9}$ Kobayasi T, Midtgard K, Asboe-Hansen G. Ultrastructure of human mast cell granules. J Ultrastruct Res 1968;23:153-65.

${ }^{10}$ Dvorak AM, Mihm MC, Dvorak HF. Morphology of DHS in man. II. Ultrastructural alterations affecting microvasculature and tissue mast cells. Lab Invest 1976;34:179-91.

"Mota I, Round Table Discussion. In: Padawer J, ed. Conference on mast cells and basophils. Ann NY Acad Sci 1963;103:441.

12 Padawar J. Mast cell degranulation in fixed preparations. Proc Soc Exp Biol 1965;120:318-21.

13 Wilson JW. Mast cell morphologic alterations after acute pulmonary injury or respiratory distress. Chest 1974;65:55-85.

14 Connell JT. Asthmatic deaths: role of the mast cell. JAMA 1971;215:769-76.

is Guerzon GM, Parb PD, Michoud MC, Hogg JC. The number and distribution of mast cells in monkey lungs. Am Rev Respir Dis 1979;119:59-66.

${ }^{16}$ Patterson R, McKenna JM, Suszko IM et al. Living histamine containing cells from the bronchial lumen of humans. J Clin Invest 1977;59:217-25.

${ }^{17}$ Dvorak HF, Dvorak AM. Basophil leucocytes: structure, function and role in disease. Clin Haematol 1975;4:651-79. 
1s Orange RP. Immunopharmacological aspects of bronchial asthma. Clin Allergy 1973;3:521-37.

19 Terzakis JA, Sommers SC, Andersson B. Neurosecretory cells of human segmental bronchi. Lab Invest 1972;26:127-9.

${ }^{20}$ Gomelich JT, Bensch KG, Liebow AA. Cells of Kulchitsky type in bronchioles and their relation to the origin of peripheral carcinoid tumour. Lab Invest 1967;17:88-98.

21 Bensch KG, Gordon GB, Miller RL. Studies on the bronchial counterpart of the Kulchitsky cells and innervation of bron- chial glands. J Ultrastruct Res 1965;12:668-86.

${ }^{22}$ McDowell EM, Barrett LA, Trump BR. Observations on smal granule cells in adult human bronchial epithelium and in carcinoid and oat cell tumours. Lab Invest 1976;34:202-6.

${ }^{23}$ Bonikos DS, Bensch KG. Endocrine cells of bronchial and bronchiolar epithelium. Am J Med 1977;63:765-71.

${ }^{24} \mathrm{McDougall} \mathrm{J}$. Endocrine-like cells in the terminal bronchioles and saccules of human fetal lung: an ultrastructural study. Thorax 1978;33:43-53.

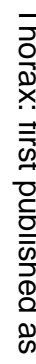

$\vec{\circ}$

$\stackrel{\overrightarrow{\vec{\omega}}}{\mathrm{O}}$ 